\title{
The Necessary Paradigm Shift in Sustainable Business Practice
}

\section{Part 2: Beyond the Triple Bottom Line}

\author{
K. R. Murray ${ }^{1} \&$ S. Boron ${ }^{2}$ \\ ${ }^{1}$ Outer Hebrides, UK \\ ${ }^{2}$ Heriot Watt University, Riccarton Campus, Edinburgh, EH 14 4AS, UK \\ Correspondence: K. R. Murray, Braeside, Breasclete, Isle of Lewis, HS2 9EF, UK. E-mail: \\ krm_tsm@yahoo.co.uk
}

Received: January 25, 2019

Accepted: February 22, 2019 Online Published: March 24, 2019

doi:10.5539/jms.v9n1p111

URL: https://doi.org/10.5539/jms.v9n1p111

\begin{abstract}
A form of "groupthink" has emerged over the last 25 years on Business Sustainable Development (SD) reporting with the Triple Bottom Line approach (TBL) being adopted wholesale by industry and government. This paper reviews the original definition (Our Common Future, 1987) and the true meaning, which has been lost over the last quarter of a century, is established. SD is essentially a process/activity that has permanence; which has a way of meeting needs and is resource availability dependent with no trade-off.

The paper goes on to summarise how the adoption of this principle has been easily integrated into the accepted International Standards Organisation's (ISO) style Environmental Management System (EMS) and Life Cycle Assessment (LCA) procedures, such that Companies can develop an alternative strategic plan B in parallel to their TBL reporting.
\end{abstract}

Keywords: total sustainability, EMS, Our Common Future, strategic planning, triple bottom line

\section{Introduction}

In the last 25 years, the Triple Bottom Line (TBL) approach to Sustainable Development (SD, Elkington, 1997) has become the accepted norm for Business reporting on SD performance (Slaper \& Hall, 2011, p. 8 summary; Jackson et al., 2011, p. 58 conclusions) and more recently (Ahmad et al., 2018; Padin et al., 2016).

In January 2019, there were over 25 million TBL web sites listed on a basic Google search compared with 3 million quoted by Alhaddi (para. 1, p. 8) 4 years earlier. That paper also pointed out that in their analysis:

... the Triple Bottom Line paradigm cannot be rescued simply by attenuating its claims: the rhetoric is badly misleading, and may in fact provide a smokescreen behind which firms can avoid truly effective social and environmental reporting and performance (p. 243).

Although the Chemical Engineering Profession, almost 20 years ago, had been told that SD was a concentricity principle (Murray, 2019, part 1 Intro). It would appeare that this TBL "groupthink" approach to SD has become the accepted definition: the adoption of the three pillars of Sustainability; Social, Environmental and Economic or People, Planet and Profit, with appropriate "trade-offs" reflect good Business Sustainability practice (Griggs et al., 2014, p. 4, para. 7; Carter \& Rogers, 2008, p. 364, para. 2).

However, in the excellent paper by Milne et al. (2013) giving an overview of the emerging SD reporting by businesses, they did suggest that it would appeare that TBL would continue to be used as a smokescreen for business as usual:

In making sense of sustainability, primarily through an ill-developed and incomplete notion of the TBL, businesses and their associated institutions have limited their ideas to issues about themselves (Sec. 6, Para. 1).

Alhaddi, in 2015, also mentioned that there was an inconsistent usage of Sustainability. The term was often being applied in fact to only one or two of the three parameters (society, environment and economy) but more often than not being used interchangeably with TBL, implying that they are one and the same. Even Holden et al, 
2014, on "Re-visiting Our Common Future", concluded that SD and Sustainability would continue to be used interchangeably by them in their paper.

Unfortunately, this inconsistency on TBL-SD and Sustainability is compounded further by the fact that economic and financial governance, both at the international and national levels, continues to remain firmly outside the remit of sustainable development and continue to function largely untouched by the concept even in its present confused form $\{S D$ faces tough competition from other paradigms (UN Report, 2012, p. 13)\}.

Ayres in 2007 (p. 126) concludes that there is plenty of room for substitution and some possibility of future major breakthroughs (weak sustainability-TBL) but, those who advocate strong sustainability (no trade off) appear to be closer to the truth than the optimists who believe in more or less unlimited substitution possibilities.

As recent as 2015 Gudmundsson et al. (Conclusions 2.6, p. 66) argues that the "weak" and "strong" forms of sustainability are somewhat academic; both help frame a continuum between an environmentally oriented business-as-usual approach to development and a radical reformulation of economic activity to keep it within macro-ecological limits.

But, in the mean time, organisations (NZ-SBC, 2016) are advocating that Business leaders "need a clear purpose, long-term focus, agile strategy and strong stakeholder relationships to remain financially, environmentally and socially sustainable".

So, it is not surprising that the futility of addressing SD is being fraught by doubts and misgivings (Morris, 2012). The Board of Directors vision of the goal that they need to achieve, a totally sustainable business, is being clouded by:

a) The accepted paradigm of TBL within the business community (Carter \& Rogers, 2008, p. 365).

b) Sweeping wish-lists of ideals being offered in the UN's Corporate Governance company guidelines (UN, Global Compact, 2014) and supply chain management (UN Global Compact, 2010).

c) Scholars arguing that SD is the same as Sustainability (Holden et al., 2014, p. 131, para. 1).

\section{Revisiting "Our Common Future" (OCF)}

The report commissioned by the World Commission on Environment and Development (OCF 1987) served as the milestone with the definition of Sustainable Development being its most quoted extract.

Sustainable development is development that meets the needs of the present without compromising the ability of future generations to meet their own needs (OCF, 1987).

This was the vision that the report was trying to put across to the world at large and which is frequently mis-used, so, it is essential to look at the specifics in this SD statement and establish that it is the form of words that hold the key: Sustainable Development is "bound" by the form of words used.

- Development: In the Chairman's forward to OCF this is clearly defined as "what we all do". In other words, it is an activity, process or procedure, that is used to satisfy our needs.

- Sustainable: Perhaps the best comparison here is the French translation "durable". Long lasting, having continuous; going on forever. Something that can have continuance.

- Needs: The central theme within OCF is the equitable access to all manner of resources required for satisfying human needs, "Maslow's hierarchy" (Koltko-Rivera, 2006), but it also expects to appreciate the inclusion of inter and intra generational equity as well as inter-economic equity as vital elements of the "needs satisfaction".

The result of this revisit to OCF clarifies and deepens our appreciation of the true meaning. We now have a concept of SD that can be applied to Business. A form of words and statements that is clear and concise and simple to apply.

1) Anything that the business does that it can continue to do on an indefinite basis is sustainable.

2) Anything that the business cannot do indefinably is unsustainable, and sustainability may be best defined as the capacity for continuance into the long-term future.

3) $\mathrm{SD}$ is an absolute definition in respect to; without compromising the ability of others.

4) $\mathrm{SD}$ is an absolute definition in respect to; ability of future generations.

The above brings out a much clearer picture for an organisation on how it should be addressing the issue of SD and SD reporting: 
$\delta$-T'ain't what you do it's the way that you do it—-that's what gets results $\mathcal{J}$ (Composers: Young \& Oliver, 1939).

Making this paradigm shift to the fact that: Sustainable Development is a process-a way of meeting needs; is resource availability dependent, with no trade off; includes the requirement for all forms of equity, and equitable access to resources changes things dramatically.

Now it is not:

1) A concept that has any ambiguity or vagueness (Morris, 2012).

2) The same as Sustainability which is an expression of continuance of "something".

Viewing this within a Business context gives a very clear set of parameters for the SD practitioner: Assess the organisations activities from cradle-to-grave and highlight those "activities" that are far removed from meeting these strict conditions, using the "Framework" (Murray \& Boron, 2019, Part 1, Table 2)

Armed then with this assessment they can then prioritise those activities which need to be addressed immediately and those which will be addressed in longer term strategic plans.

\section{Total Sustainability (TS)}

Total Sustainability has crept into the literature over the last 40 years without necessarily clearly defining exactly what it is describing or meaning (Pearson, 2013). However, the excellent review of SD-Corporate Social Responsibility (CSR) reporting (Alshehhi et al., 2018) gives us the answer. It covered some +130 articles relating to sustainability and corporate responsibility and found that:

Articles in the single-dimension group tackle only one dimension of sustainability: economic, environmental, or social.

There are two combinations of double-dimensions: economical-environmental and social-environmental.

The third group is made up of total sustainability, with the combined effect of the three dimensions rather than individual or a combination of dimensions (Result 3.4).

From this we can conclude that the TS reporting as found in their review relates directly to the Triple Bottom Line (TBL) definition of Sustainable Development as proposed by Elkington.

But the central concept to TS is the acceptance of the fundamental values (Daly, 2007) which are not negotiable, namely: ecological sustainability, basic human needs, intra-generational equity and inter-generational equity and the true TS concept demands that economics is constrained, firstly by environmental and secondarily by social limits (Murray \& Boron, 2019, Part 1. Intro).

Now with that clarification of what SD actually means for an organization a SD professional can very easily review the "way of doing things" and create a strategic plan that will remove the undermining of resource availability either environmental or social in any of the processes or systems it (the company) has in place in supplying welfare to the population or the individual. This plan can then be enacted if and when the Economic System actively encourages and rewards sustainability in business.

It is strange that almost 50 years ago it was being suggested that the Economic System should "actively encourage" a capacity for continuance (Schumacher, 1973), well before SD became fashionable.

We must study the economics of permanence. Nothing makes economic sense unless its continuance for a long time can be projected without running into absurdities (p. 26).

\section{Management Systems-Historical Development}

There has been a rapid rise in the number of management systems published and adopted by businesses. Three of the most widely adopted are Quality, Environment and Health and Safety (Table 1) with the most successful, ISO 14001 and 9000 , having +1.5 and $1.0 \times 10^{6}$ companies respectively externally audited and certified in 2015 (ISO web site accessed April, 2018).

As the style and format of management systems are often very similar, companies have attempted to integrate these into their specific overall company management system and an excellent overview of the relative success in integrating the various Management Systems (MSs) and their inter-relationship with CSR (Bernal-Conesa et al., 2016) highlighted that there appeared to be a tendency for the organisations to make compromises when TBL issues were being considered. (Conclusions, para. 4, p. 129)

An earlier review (Bernardo et al., 2012) concluded that organisations implementing three MSs, i.e., QMS, EMS and CSR may find difficulties in their integration due to "internal organisation issue" while those who are 
willing to consider integrating two, namely QMS and EMS should not have these compromising issues (Conclusions, para. 7, p. 31).

Table 1. Selected International Standards Organisation (ISO) management systems

\begin{tabular}{lll}
\hline ISO Standard & Management System & Area of responsibility \\
\hline 9001 & Quality Management Systems & Quality \\
30301 & Information/Documentation/Records & Business \\
55001 & Asset management Systems & Finance \\
14001 & Environment Management Systems & Environment \\
45001 & Occupational H.\& S. Management Systems & Health and Safety \\
26000 & Social Responsibility guidance & Overall Company performance \\
\hline
\end{tabular}

Back in 2007, Sebhatu and Enquist examined the process of change within a specific company that had implemented ISO 14001 for over 10 years and how that had acted as a driving force for sustainable development. They concluded that an EMS like ISO 14001 could be used as an "active tool" for promoting organisational change towards TBL-SD.

With the introduction to corporate sustainability, Visser in 2007 suggested that this be considered as a values-laden umbrella concept, which refers to the way in which the interface between business, society and the environment is managed (p. 1, para. 4).

About the same time, it was reported (Globespan, 2006) that this TBL conception of corporate sustainability was now widely used among business practitioners; the World Business Council on Sustainable Development (WBCSD) claiming that it brought together its 180 members international companies "in a shared commitment to sustainable development through economic growth, ecological balance and social progress".

Finally, in an analysis as to how ISO 14001 might be used to advance corporate sustainability practices and performance, Maletic et al. (2015) reported that as expected it does set up a framework for an organization to reduce its environmental impact, but it also can support the actions and the expectations required to improve the corporate TBL-SD performance.

Unfortunately, integrating SD into Corporate Social Responsibility (CSR) through the plethora of SD systems that have come to the surface over the last 20 years, for example, SIX-SIGMA (Anbari, 2002), The Natural Step (Nattrass \& Altomare, 1999) and CERES (2019) have produced the doubts and misgivings expressed by Morris in 2012 and it is little wonder that addressing the range of issues to be considered across the spectra of the ten headings, from Global Initiatives through Human/Labour Rights to Corruption, Sector Agreements and Implementation (Leipziger, 2010) has given rise to confusion when all the options, participating experts, consultants and NGO's put in their penny-worth?

It would appeare that even with the best of intensions it becomes very much "a paper exercise or window dressing" with respect to the concept of Total Sustainability, the objective/target of SD strategic plan.

It is no little surprise therefore that although these excellent management systems are in place, business leaders still find themselves struggling in their forward vision, unclear in purpose, long-term focus and strategy that allows them to remain financially, environmentally and socially sustainable without reverting to the TBL approach.

\section{TS Management System Applied}

With the capacity for continuance of a company being governed very much by the way it looks after its underpinning resources, it must develop a strategy that takes it from its current unsustainable behaviours/activities. To do this it must:

- Initiate a procedure that identifies the current risks from unsustainable behaviours.

- Assess their significance in terms of the long-term threat to company continuance.

- Create a plan and strategy to reduce and even eliminate their effect on the company.

To start developing a "permanence" SD strategy plan, a procedural framework similars to that which must exist for accreditation in the ISO standards, is need (Boron \& Murray, 2004) and with the clearly defined reality of business SD, a simplified LCA approach (Boron \& Murray, 2005; Selmes et al., 1997) makes the ISO style framework into a rigid and dedicated Management Strategy Tool (MST) for continuance. 
The purpose of this procedure is: the detection of un-sustainability hot spots across all the company operations with no attempt at truncating the analysis into a "cradle to gate" approach. This removes all relativism, and, the effectiveness of actions is immediately obvious when viewed relative to the absolute goal of TS. Targeted problems are relegated to their rightful place; being only symptoms of un-sustainabilities within processes (Boron et al., 2017).

For a manufacturer, the agenda is to either keep the un-sustainable market threat at bay or try to achieve sustainability for that operation. Either way, the enterprise must choose the applications and tools that are most effective.

The most poignant aspect to this approach is that there are essentially only 3 primary questions that need to be asked:

1) What are the activities, cradle-to-grave, that undermines our ability to survive?

2) What are the risks to our business from these un-sustainabilities?

3) How can these unsustainable activities be diminished and/or eliminated altogether?

As the business is more than just the factory, the appraisal must include all supply chains and all use phase areas served by the goods and services produced and the resources that underpin the company. However, just like ISO 14001, a base-line study, using the TS framework (Murray \& Boron 2019, Part 1, Table 2) and a classical process flow diagram of the organisations activities within the boundaries of the existing factory fence, getting started mirrors the ISO14001 procedures, i.e., an input-process-output approach on each of the company's in house operations. Sustainability risk assessment is done based on the significance given to the loss of resource availability, this being defined as a Resource Availability Infringement (RAI).

Progressively, throughout the organisations in house activities, a portfolio of RAI's is built up and this establishes two primary aspect streams; those that have a direct relationship with the environment and those that have an indirect relationship, namely those that are associated with either upstream or downstream activities.

As the business is more than just the factory, it is relatively easy to extend the company's responsibility beyond the factory fence and so the criterion that determines the sustainability of an operation, the undermining of the resource base, is then applied across the organisation's operations from cradle to grave (Figure 1).

The outcome of this procedure identifies the un-sustainable aspects and activities within the entire cradle to grave extent of business operations and any un-sustainability inherent in the overall company's operations are discovered and noted.

\section{Discussion}

Using this approach, without spending an unwarranted amount of time and energy on feasibility studies, it often becomes apparent that no matter how they try some operations within the organisation are inherently unsustainable and a significant risk assessment can then be made as to the degree of effect that that infringement has on the long-term continuance of the activity in its present form.

However, through this procedure an overall strategic sustainability management policy can be formulated and in the same way as is structured within ISO14001, it would be reviewed on a regular basis with revised objectives and targets reflecting the prevailing economic climate.

Needless to say the development of this TSM procedure has gone through considerable changes over the last decade, however, this approach to SD creates difficulties for many who come to the program; they know that SD means TBL (Boron et al., 2017)! This state of affairs has been getting worse in the last decade due to the prevailing disorientation, confusion and lack of focus on all things "sustainable" in both industrial (Rowe \& Bansal, 2013, pt. 4, 5 \& 10) and academic circles (Jones et al., 2010, p. 330, para. 2).

Interestingly too, there is also a reluctance, particularly within that group of SD professionals, to accept the concept of zero RAI i.e., the enterprise's primary target for Total Sustainability. Like Quality Managers who cannot accept the concept of zero defects (Crosby, 1979) in Total Quality Management as it is an "unrealistic/uneconomic" objective (Anvari et al., 2011). Let us hope the same will not be said in 30 years to the acceptance of zero RAI's for Total Sustainability Management.

\section{Conclusion}

It is important to reiterate the conclusions presented in Part 1(Murray \& Boron 2019): Historical perceptions have moulded existing management behaviour and practices, and, unfortunately both they and SD business practitioners need to make the paradigm shift: TBL-SD to TS reporting. 
In summary for Businesses

- SD is a process - a way of meeting needs; is resource availability dependent, with no trade off.

- Capacity for continuance of that specific activity/process is governed by resource availability.

- The company need a strategy that removes those unsustainable behaviours/activities.

- To achieve TS - there must be no undermining of resource availability either environmental or social in any of the processes or systems the company has in place in supplying welfare to the population or the individual.

- The TSM procedure implementation (Boron et al., 2017) allows companies to explore the full extent of their business un-sustainability

- Organisation can create a "pro-active" strategy for the achievement of sustainable development for its industrial process or business from cradle to grave.

- The enterprise can create a strategic "permanence plan B" which may/may not be implemented as and when the economic/social climate prevails.

- The company can appreciate and understand the limitations of their prevailing SD activities.

- The Board can fully appreciate the interaction of its business with the environment, economics and society.

Elementary flows cirectly from and to the environment

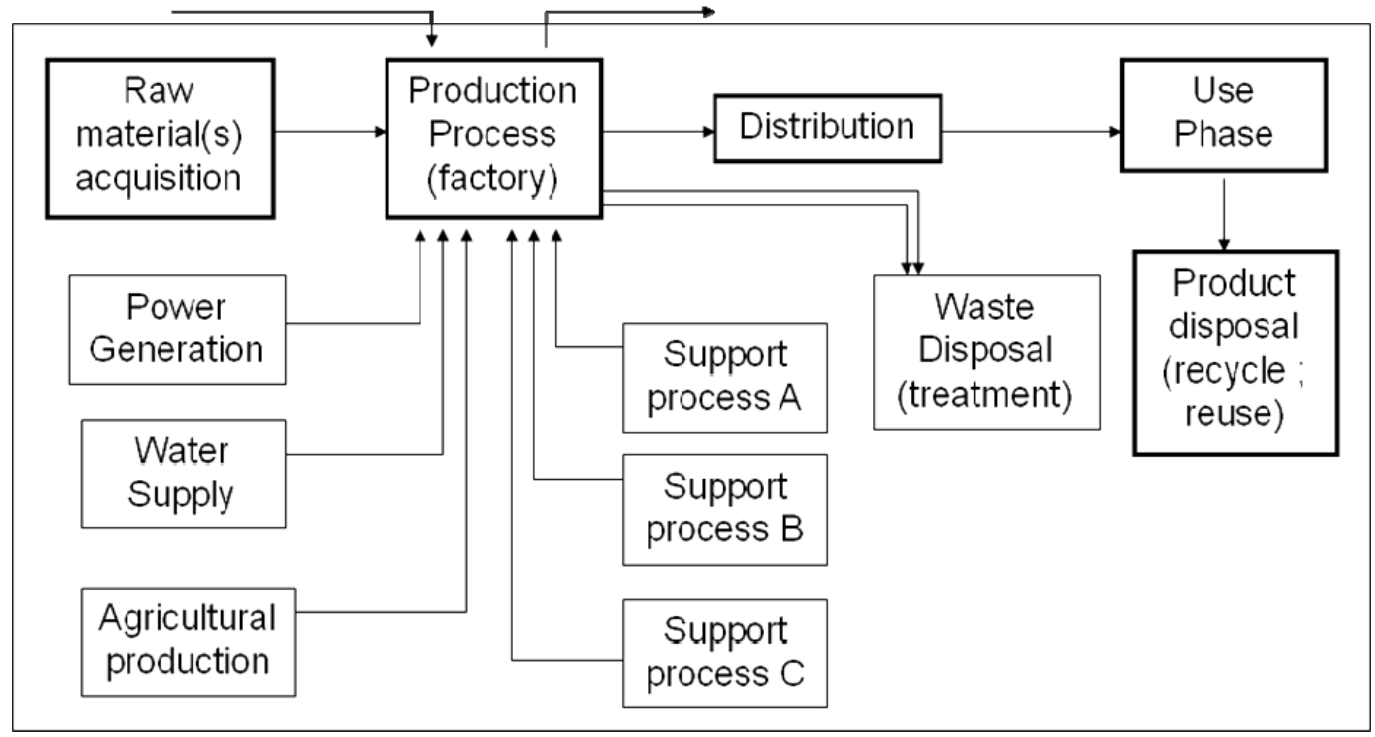

Figure 1. Cradle to grave view "beyond" the factory fence

\section{References}

Ahmad, S., Wong, K. Y., \& Rajoo, S. (2018). Sustainability indicators for manufacturing sectors: A literature survey and maturity analysis from the triple-bottom line perspective. J. of Manufacturing. Tech. Man. (Article in Press). Retrieved Jan., 2019, from https://www.scopus.com/inward/record.uri?eid=2-s2.0-85055291408\&doi=10.1108\%2fJMTM-03-2018-00 91\&partnerID=40\&md5=78444fe10a2bf868d70c8e9d4d520087

Alshehhi, A., Nobanee, H., \& Khare, N. (2018). The Impact of Sustainability Practices on Corporate Financial Performance: Literature Trends and Future Research Potential. Sustainability, 10, 494. https://doi.org/10.3390/su10020494

Alhaddi, H. (2015). Triple Bottom Line and Sustainability: A Literature Review. Bus. \& Man. Stud., 1(2), 6-10. https://doi.org/10.11114/bms.v1i2.752

Anbari, F. T. (2002). Six sigma method and its applications in project management. Project Management Institute Annual Seminars, Project Management Institute. Retrieved Jan., 2019, from https:/www.pmi.org/learning/library/six-sigma-method-applications-pm-8515 
Anvari, A., Ismail, Y., \& Hojjati, S. M. H. (2011). A Study on Total Quality Management and Lean Manufacturing: Through Lean Thinking Approach. J. World Applied Sciences, 12(9), 1585-1596.

Ayres, R. U. (2007). On the practical limits to substitution. Ecological Economics, 61, 115-128. https://doi.org/10.1016/j.ecolecon.2006.02.011

Bernal-Conesa, A., Briones-Peñalver, A. J., \& De Nieves-Nieto, C. ( 2016). The integration of CSR management systems and their influence on the performance of technology companies. Eu. J. of Man. \& Bus. Econ., 25(3), 121-132. https://doi.org/10.1016/j.redeen.2016.07.002

Bernardo, M., Casadesus, M., Karapetrovic, S., \& Heras, I. (2012). Do integration difficulties influence management system integration levels? J. of Cleaner Prod., 21(1), 23-33. https://doi.org/10.1016/j.jclepro.2011.09.008

Boron, S., \& Murray, K. R. (2004). Bridging the Unsustainability Gap: a Framework for Sustainable Development. Sustainable Development, 12, 65-73. https://doi.org/10.1002/sd.231

Boron, S., \& Murray, K. R. (2005). The contribution of a modified LCA methodology to Total Sustainability Management (TSM): a strategy for sustainable development in industry (Paper 0154-002). 7th World Congress of Chem. Eng, Glasgow, Scotland, UK.

Boron, S., Murray, K. R., \& Thomson, G. (2017). Sustainability Education: Towards Total Sustainability Management Teaching. In F. W. Leal, L. Brandli, P. Castro \& J. Newman (Eds.), Handbook of Theory and Practice of Sustainable Development in Higher Education (Volume 1). Berlin: Springer. https://doi.org/10.1007/978-3-319-47868-5_3

Carter, C. R., \& Rogers, D. S. (2008). A framework of sustainable supply chain management: moving toward new theory. I. J. of Phy. Dist. \& Log. Man., 38(5), 360-387, https://doi.org/10.1108/09600030810882816

CERES. (2019). The Ceres Roadmap for Sustainability. Retrieved Dec., 2018, from https://www.ceres.org/about-us

Crosby, P. B. (1979). Quality is Free. New York: McGraw-Hill.

Daly, H. E. (2007). Ecological Economics and Sustainable Development, Selected Essays of Herman Daly. Elgar, Cheltenham, UK. https://doi.org/10.4337/9781847206947

Elkington, J. (1997). Cannibals with forks-Triple bottom line of 21 st century business. Stoney Creek, CT: New Society Publishers.

Globescan. (2006). Survey Report of Sustainability Experts. Toronto: Globescan.

Griggs, D., Stafford, S. M., Rockström, J., Öhman, M. C., Gaffney, O., Glaser, G., Kanie, N., Noble, I., Steffen W., \& Shyamsundar, P. (2014). An integrated framework for sustainable development goals. Ecology and Society, 19(4), 49. https://doi.org/10.5751/ES-07082-190449

Gudmundsson, H., Hall, R. P., Marsden, G., \& Zietsman, J. (2015). Sustainable Transportation. Springer Texts in Business and Economics, Springer-Verlag Berlin Heidelberg. https://doi.org/10.1007/978-3-662-46924-8_2

Holden, E., Linnerud, K., \& Banister, D. (2014). Sustainable development: Our Common Future revisited. Global Environmental Change, 26, 130-139. https://doi.org/10.1016/j.gloenvcha.2014.04.006

Jones, P. D., Selby, D., \& Sterling, S. (2010). Sustainability Education: Perspectives and practice across Higher Education. Earthspan.

Koltko-Rivera, M. E. (2006). Rediscovering the Later Version of Maslow's Hierarchy of Needs: Self-Transcendence and Opportunities for Theory, Research, and Unification. Review of General Psychology, 10, 302-317. https://doi.org/10.1037/1089-2680.10.4.302

Leipziger, D. (2010). The Corporate Responsibility Code Book (2nd ed.). Pub. Greenleaf.

Maletič, M., Podpečan, M., \& Maletič, D. (2015). ISO 14001 in a corporate sustainability context: a multiple case study approach. Int. J. Man. of Env. Qual., 26(6), 872-890. https://doi.org/10.1108/MEQ-08-2014-0129

Milne, M. J., Bell, A., \& Gray, R. (2013). W(h)ither Ecology? The Triple Bottom Line, the Global Reporting Initiative, and Corporate Sustainability Reporting. J. Of Bus. Ethics, 118(1), 13-29. https://doi.org/10.1007/s10551-012-1543-8 
Morris, M. (2012). Sustainability: An Exercise in Futility. I. J. of Bus. \& Man., 7(2).

Nattrass, B., \& Altomare, M. (1999). The Natural Step for Business. USA: Pub. New Society.

NZ-Sustainable Business Council. (2016). Business Case for Sustainability. Retrieved Nov., 2018, from http://www.sbc.org.nz/_data/assets/pdf_file/0006/118473/SBC_Business-CaseForSustainability_

Our Common Future. (1987). World Commission on Environment and Development. Oxford University Press.

Padin, C., Ferro, C., Wagner, B., Valera, J. C. S., Høgevold, N. M., \& Svensson, G. (2016). Validating a triple bottom line construct and reasons for implementing sustainable business practices in companies and their business networks. Corporate Governance (Bingley), 16(5), 849-865. https://doi.org/10.1108/CG-12-2015-0163

Pearson, I. (2013). Total Sustainability: Pub. CreateSpace Ind. Pub. Platform. Retrieved March, 2018, from $\mathrm{http}: / / \mathrm{www}$. worldfinancialreview.com/? $\mathrm{p}=3183$

Porritt, J. (2005). Capitalism: As if the world matters. Earthscan.

Rowe, A., \& Bansal, T. (2013). Retrieved Nov., 2017, from https://iveybusinessjournal.com/publication/ten-ways-to-help-companies-become-sustainable-in-2013/

Schumacher, E. F. (1973). Small is beautiful: a study of economics as if people mattered. Pub. Blond \& Briggs.

Sebhatu, S. P., \& Enquist, B. (2007). ISO 14001 as a driving force for sustainable development and value creation. The TQM Magazine, 19(5), 468-482. https://doi.org/10.1108/09544780710817883

Selmes, D. G., Boron, S., \& Murray, K. R. (1997). Industry, Life Cycle Assessment and Sustainability. I. Chem. E. Research Event, 1, 153-156.

U.N., Dept. of Econ. \& Soc. Aff. (2012). Back to Our Common Future- Sustainable Development in the 21st century (SD21) project.

UN, Global Compact. (2010). Supply Chain Sustainability. Retriecved Dec., 2018, from https://www.bsr.org/reports/BSR_UNGC_SupplyChainReport.pdf

UN, Global Compact. (2014). Guide to Corporate Sustainability-Shaping a sustainable future. Retrieved Nov., 2018, from https://www.globalcompact.de/wAssets/docs/Nachhaltigkeits-CSR-Management/un_global_compact_guide _to_corporate_sustainability.pdf

Visser, W. (2007). Corporate Sustainability and the Individual: A Literature Review. Cambridge Programme for Sustainability Leadership Paper Series, No. 1.

Young, J., \& Oliver, S. (1939). Retrieved Oct., 2017, from http://www.songtexte.com/songtext/ella-fitzgerald/taint-what-you-do-its-the-way-that-cha-do-it-23d7306f.h tml

\section{Copyrights}

Copyright for this article is retained by the authors, with first publication rights granted to the journal.

This is an open-access article distributed under the terms and conditions of the Creative Commons Attribution license (http://creativecommons.org/licenses/by/4.0). 